\section{THE JOHN INNES HORTICULTURAL INSTITUTION}

$\mathrm{T}$

HE John Innes Horticultural Institution is to move from Merton to a new site at Bayfordbury in Hertfordshire. The move will mean a radical change in the scale of work and the opportunities for studying the problems of horticulture. It is therefore worth while considering these prospects in relation to the past work and development of the Institution.

The foundation was due to a private bequest. When Mr. John Innes died at Merton in 1904, he left the greater part of his fortune to endow an institution to be set up at Merton "for the improvement of horticulture". In 1909, the Charity Commissioners approved a scheme for the new Institution which was to concern itself, on one hand, with the training of
Bateson should be applied and taught on the spot. The Institution has therefore always held pure research and applied research equally balanced, using each to feed the other. Following this habit, it has always been able to attack its own problems in its own way, and its programme has been a selfpropagating one.

The new theories and techniques had to be fitted into the larger framework of science, and, in the process, some false steps were taken, as indeed they were bound to be. The first appointment to the staff, however, was a success : E. J. Allard, a fine gardener and a wise teacher, was made curator. From the first, too, the genetic work with fruit crops met with success. M. B. Crane, who was one of the earliest products of the new training, was put in charge of this branch in 1919. The full possibilities of plant breeding, however, waited upon the second

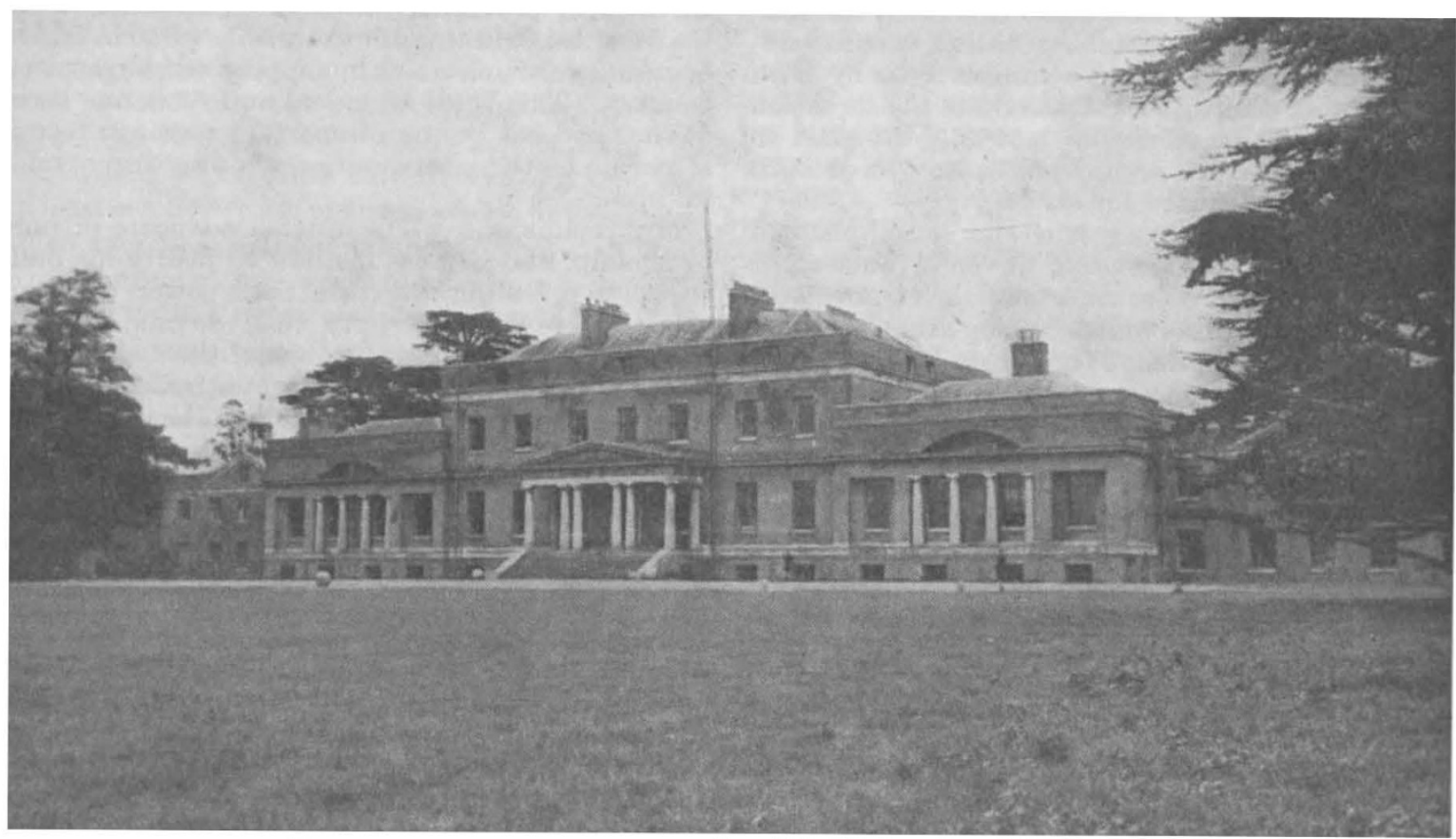

BAYKORDBURY, THE NEW HOME OF THE JOHN INNES HORTICULTURAL INSTITUTION

gardeners and, on the other hand, with "research, whether of a scientific or practical nature, into any matters having reference to the growth of trees and plants generally".

The administering Council represented universities and public bodies, including the Ministry of Agrieulture. The first step it took was in the choice of a director. This step was decisive, for the choice was William Bateson. At this time Bateson was not only an outstanding personality in British science, but he was also engaged in the tremendous struggle-not yet won in his own country-to establish the new science of genetics. In British universities no facilities existed for research in genetics, and its teaching met with opposition rather than encouragement. To Bateson, therefore, the appointment meant a foothold, a first secure foothold, for genetical research in Britain. To the new foundation it meant a policy and a programme which filled a gap in the national development of science. At the same time, the terms of the foundation required, or ensured, that the fundamental methods of inquiry introduced by decisive step in the development of the Institution. This step was taken by Bateson following his visit to the headquarters of the Drosophila school in 1921. $\mathrm{He}$ then realized that the next great advances in genetics would demand that the study of chromosomes should go hand in hand with experimental breeding. He accordingly invited the late W. C. F. Newton to establish this second new theory and technique at Merton. Once again a serious gap in the national scheme of research was filled by Bateson's initiative. A school developed, and foreign workers played an important part in its growth. Vavilov and Sturtevant, and later Karpechenko, Belar and Müntzing made their varied contributions to the work; and the visits of Johannsen and Morgan, Lotsy, Winge and Mohr, Driesch, Baur and Goldschmidt enlivened the frequent and often lengthy arguments in the library, laboratories and fields at Merton.

After Bateson's sudden death in 1926, the same policies were continued by Sir Daniel Hall. But very naturally a synthesis also began to take place. 
Mendelian experiment and chromosome observation were combined in the work of J. B. S. Haldane and, in a different way, in that of C. D. Darlington. The foundations of plant breeding, especially in the fruits, were changed by the discovery of polyploid series related in various ways to hybridization and recombination, as well as to fertility and vigour. At the same time, to meet the exacting needs of plant breeding, improvements in the quality and precision of glasshouse cultivation were demanded. W. J. C. Lawrence, Allard's successor, and a second of the Institution's own students, achieved these improvements, and the fruits of his success have been reaped by the industry at large.

In October 1939 Sir Daniel Hall was succeeded as director by C. D. Darlington. In spite of war conditions, K. Mather, now head of the Genetics Department, was able to introduce and perfect another new scientific method. It was based on applying the Mendelian and chromosome theories in combination with Fisher's statistical methods. It made use of parallel studies on quantitative inheritance, or continuous variation, in the fly Drosophila and in crop plants. The results have an undoubted practical bearing on plant breeding; and they also have the fundamental value that they finally reconcile the hard-dying conflicts of Darwinian and Mendelian theory, of biometry and genetics. During the same period, at several angles, chromosome studies have been shown in their broad and fundamental bearing on medical research, in the recognition, etiology, and $\mathrm{X}$-ray treatment of cancer, and in the understanding of the development of the blood. With new methods the study of the cell is proving to be as useful in the approach to development and disease as it has been in the approach to heredity.

During the War, the scientific staff was reduced from sixteen to six, and long-term projects had of course to be replaced in part by more immediately useful trials and experiments. The practical results of this work have been made known to the grower and cultivator by leaflets, bulletins and by advisory service. These activities will doubtless have to remain after the War : it is clearly not enough for the harvest of research to be stored-or buried-in libraries. Future developments, however, will depend on the success of the major operation of transplanting the Institution and on its economic situation afterwards.

When the permanent buildings, laboratories and glasshouses were put up in 1910 , it was already known from A. D. Hall's report that the site and soil were poorly suited to the purpose. Both went from bad to worse. The vicinity was clothed with suburb after the last War ; the air was polluted, the sunlight cut down, the water-table lowered, the garden pests multiplied and strengthened, while miles of houses and factories cut off all avenue for expansion and all contact with the one industry that mattered. As fast as its building value went up, the horticultural value of the land went down. The workers outgrew the laboratories, the books outgrew the library, the experiments outgrew the gardens. Setting up overflow stations could merely postpone the decision. A new site had to be found.

Inquiries for new land were begun in 1938. They continued over a wide area for seven years. The quality and drainage of the soil, the atmosphere and slimate, the water and electricity supply, the availability of buildings, the accessibility to town and university, all had to be taken into account. Commercial value also had to be regarded. The Institu- tion's revenue, reduced in 1931, was still further curtailed in 1941 by the war damage in London, which was even more serious in its financial effects than the direct destruction at Merton in 1944.

The John Innes Trustees have chosen a site which meets these various requirements better than had seemed possible. They are exchanging 19 acres at Merton for 372 acres on the new site. While Merton is eight miles from the centre of London, Bayfordbury is sixteen miles away. It is one mile from Bayford Station and less than a mile from the outskirts of Hertford. Yet the district, for the last hundred years, has been unfashionable enough to have remained rural. Indeed Bayford (to quote the Greater London Plan, 1944) "is in the centre of a very extensive belt of woodland... one of the fow really unspoilt tracts of land near London, from which it is readily accessible". The soil is based on glacial drift over chalk and varies from a light to a medium-heavy loam. The land lies on the south side of the River Lea, and rises a hundred feet above it. The slopes should give safety from frost without undue exposure to wind. Conditions so favourable as these are not easily found near London.

Bayfordbury was built in the years after 1759 by William Baker, nephew-in-law of Tonson, the publisher of Milton and Dryden. Until this year it housed the collection of Kneller's portraits of his forty-two friends or clients, members of the Kit Cat Club, which has now been acquired by the nation. The profits of "Paradise Lost" paid' for a substantial building. The mansion is conveniently designed and centrally placed. It is handsomely sited between two groups of cedars of its own age. A lake near by, fed by surface drainage, affords a plentiful supply of water for irrigation. The woodlands include the collection of conifers, occupying ten acres and recorded in the four-volume work of Clinton-Baker and Jackson. This collection was established in 1838 by W. R. Baker with the advice of Loudon. Now it might well prove of value in the study and breeding of both ormamental and timber trees.

The mansion and outbuildings provide nearly twice the accommodation at present available at Merton. Some of this will be useful for domestic housing. But even with the six additional cottages it will clearly not go far towards solving the housing problem. With their dependants, the staff number, in peacetime, about 120 , and under present conditions their removal as a whole to a new locality will demand new housing. The necessary building will probably not be completed for two years or more.

The question remains as to why such a sudden expansion of area is made. Can profitable use be made of so large an area for horticultural, and especially genetic, research ? The original land purchased at Merton was five acres, and only piece by piece were acres added to it-so long as they could be added, and always at an increased price. Other research stations have suffered from outgrowing their land after twenty or thirty years with like consequences. The Royal Botanic Gardens, Kew, were larger and the difficulty came late but, having come, proves insuperable. With the Royal Horticultural Society's gardens at Chiswick the difficulty was overcome by removal; and the new gardens at Wisley, like those at Kew, are of similar size to Bayfordbury. Of the 372 acres in the new estate, no more than 150 acres will, it is expected, be taken up for research purposes in the next ten years. But the choice of a larger area for the John Innes land is based on the 
expectations of fifty years. It is also based on the view that the need for research, and the understanding of that need, are likely to grow beyond our present computations. This view takes into account two lessons of the war period. One is that horticulture has changed from an incidental luxury into a necessary part of the nation's economy. The other is that genetics has changed from an ornament of research to one of the main props of science.

In its new habitation, the John Innes Institution will undoubtedly undergo a transformation. But there seems no reason why it should forsake the character or the aim for which it has been valued. Its aim will no doubt continue to be to unite theory with practice and to combine a freedom of initiative with some coherence of purpose within the wide range of activities allowed by its foundation.

\section{THE TEACHING OF ANALYTICAL CHEMISTRY IN GREAT BRITAIN : WITH SPECIAL REFERENCE TO MICROCHEMISTRY}

\section{BY DR. CECIL L. WILSON}

$\mathrm{F}^{\mathrm{o}}$ OR some time past it has not been possible to make any accurate estimate of how the demand for microchemical teaching in the British Isles has been met. Previously, the only guide in this direction was the list, probably not altogether comprehensive, published from time to time in Mikrochemie before the War. As a consequence, discussion of the teaching of microchemistry must of necessity have been based largely on estimates derived solely from personal contacts and hearsay, and any statement about it was justly open to doubt.

The only satisfactory way to clear up the position was by means of some sort of census. This was scarcely an undertaking for a private individual. The recent formation of the Microchemistry Group of the Society of Public Analysts and Other Analytical Chemists, however, provided an official body to which the information is of first importance. At the request of the Committee of this Group (under the chairmanship of Prof. H. V. A. Briscoe, Imperial College of Science and Technology, London), therefore, a questionnaire was drawn up, the answers to which would clarify the position of the teaching of modern analytical methods, and, in particular, of microchemistry. This questionnaire has been circulated to 85 centres of higher chemical education in the British Isles, comprising 43 universities, university colleges and university institutes, and 42 technical institutions. Replies have been received from 64 of the institutions -75 per cent of the total covered-made up of 32 universities and their institutes and 32 technical colleges. The information contained in the replies has been collated, and forms the basis of this report.

It was difficult to draw up a questionnaire which would cover the situation both completely and in detail. In fact, study of the replies suggests that such an achievement would have been impossible. But it must be acknowledged that most of the institutions received the questionnaire in an extremely helpful spirit, and did their best to interpret doubtful questions so as to supply the maximum of useful information. Many institutions made valuable additional comments, and it is perhaps in these that most food for thought will be found.
In spite of this co-operation, some points were missed completely, while others still remain vague. For example, as was pointed out in one reply, one question which should have been asked, and was not, concerned the number of microchemical balances possessed by each institution. Answers to this might conceivably have been useful in clearing up certain vagueness in other replies. Again, confusion in nomenclature, more particularly as between the terms 'micro' and 'semi-micro', is apparent; while some institutions probably put a much wider interpretation than was intended on a question which asked for information about special courses dealing with modern analytical techniques. This gives rise to doubts as to whether the teaching of any of the more modern techniques is really as advanced. as is suggested by a superficial study of the replies.

As a consequence, it has been necessary, in reporting, to interpret equally broadly on occasion. But it is felt that, at least so far as microchemistry is concerned, this summary presents a much more coherent and truthful picture than has hitherto boen available. Where it has been thought desirable, distinction has been made between the technical colleges and the universities, as the conditions ruling in each of these groups, and controlling their activities, are markedly different in many ways.

\section{Modern Analytical Methods}

Of the 64 institutions replying, 25 normally teach electrochemical analysis, 16 teach spectrographic analysis, and 25 teach electrometric methods. One or two of these courses of instruction have been interrupted owing to the War. In addition, 5 institutions teach the use of the polarograph, 12 colorimetry photometry, 2 metallurgical analysis, and 10 report miscellaneous or unspecified courses.

It is probable, as already suggested, that in many cases this instruction merely forms part of an existing course in general chemistry, and is not a special course. There are, however, certain institutions the replies from which indicate clearly that in their case the courses are special ones dealing only with the methods specified, in a reasonably detailed fashion.

Only 3 of the institutions replying possess a special lectureship in analytical chemistry. However, 12 other institutions find it necessary to qualify the negative reply by stating either that they have a lecturer concerned solely or almost solely with this branch of work, or that such a lectureship is desirable or projected.

\section{Microchemistry}

In all, 43 of the institutions, that is, almost 70 per cent, have taught or teach microchemistry in some form or another.

The first course in microchemistry in Britain appears to have been established in 1929. Of the 20 institutions which give a date for the commencement of their course or courses, 16 started prior to the War, only 4 since. This is quite to be expected. The peak years for new courses were around 1936-38.

Estimates were given by 22 institutions of the time spent on micro work. These estimates range, rather startlingly, from 4 hours per student to 300 hours. Examining these figures rather more closely, an average value for the 22 institutions is just over 65 hours per student. Of the individual estimates, 6 lie above the 100-hour mark, and 12 above 50 hours. Rather surprisingly, these figures are distributed fairly equally between universities and technical colleges. 